\title{
Comparative Analysis Of The Biggest Banking Performance In Indonesia
}

\author{
Triska Dewi Pramitasari \\ triska_dewi@unars.ac.id \\ Universitas Abdurachman Saleh Situbondo, Situbondo, East Java
}

\begin{abstract}
Covid-19 hit the ASEAN banking industry, especially Indonesia, through weaker economic growth, which resulted in slowing credit growth and resulting in declining profitability. This study aims to analyze banking performance before and after the Covid-19 pandemic. The sampling method uses the saturated sampling method (census) where there is only one sample, namely Bank Rakyat Indonesia (Persero) Tbk. The data in this study are secondary data was obtained from the banking quarterly annual report 2019-2020 period accessed through the IDX website. Performance is measured using ROA, NPL and LDR indicators with the Paired T-Test. This study found that financial ratios are in the form of ROA and LDR before and after the Covid-19 pandemic had significantly different values, while the NPL were not significantly different. In general there are significant differences in the performance of the largest banks in Indonesia before and after the Covid-19 pandemic.
\end{abstract}

Keywords: Covid-19 Pandemic ; Banking ; Financial performance ; Financial ratio

\section{Introduction}

The Covid-19 pandemic had a huge impact on the economies of many countries in the world, including Indonesia . Several business sectors were affected by the Covid-19 pandemic, among them the banking sector. Covid-19 hit the ASEAN banking sector including Indonesia through economic growth weakened, resulting in a slowdown in credit growth and resulted in decrease profitability banking. It can be concluded that the financial performance of banks will weaken in line with the increasingly widespread distribution of Covid-19 [1] .

Banking financial performance can be used as a tool in measuring banking operational activities, whether it has gone according to plan or not. The financial performance of the banking system can also be used as an evaluation material for a banking period. Financial performance can be measured using financial statement analysis. Financial statements need to be analyzed so that it can be easier for readers to obtain financial information for a bank in a certain period. Analysis of financial statements can be done by calculating financial ratios sourced from financial statements [2] .

There are many indicators used in assessing the effectiveness of banking performance. Return on Asset (ROA) is a type of profitability ratio that is used as an indicator in assessing the effectiveness of a bank in generating profits by utilizing assets owned by the bank. The next variable is the Non Performing Loan (NPL) as a management indicator in managing credit extended by banks. Meanwhile, as a function of channeling funds to the public, the use of Loan to Deposit Ratio (LDR) is used as an indicator in measuring the performance of banks in terms of the amount of credit extended by banks [3] .

The object of this research is the largest bank in Indonesia, namely Bank Rakyat Indonesia (Persero) Tbk. When the Covid-19 pandemic occurred there was a phenomenon in the banking 
world where many countries experienced a decline in the economy, but not with banks in Indonesia, especially BRI. During the hearing (RDP) with the House of Representatives (DPR) Commission VI, President Director of PT Bank Rakyat Indonesia Tbk (BRI) Sunarso said that the performance of the Persero's banks up to the first quarter of 2020 was still positive. It is recorded that the total bank credit that is included in the Association of StateOwned Banks (Himbara) is still growing by $11.03 \%$ on an annual basis or year on year (yoy) to Rp 2,469.32 trillion, where BRI Bank recorded a loan increase of $9.39 \%$ yoy which was the largest portfolio of all Himbara banks, reaching Rp 884.27 trillion. Meanwhile, in terms of raising funds, total third party funds (DPK) recorded as of March 2020 also increased from $10.23 \%$ yoy to $\mathrm{Rp} 2,611.45$ trillion, where BRI increased by $9.81 \%$ per year [4]. With this phenomenon, the researcher is motivated to raise this into a gap phenomenon in this study by focusing on BRI Bank because of the need for research limitations.

This kind of research has also been carried out by several previous studies, in which these studies reveal a research gap regarding the comparison of financial performance of banks before and after an event (in a different period). There were no significant differences in financial performance in terms of ROA values before and after the acquisition. The increase in total assets occurred after the acquisition because the company got an injection of funds from bank. The increase in net income obtained is still fluctuating, but the change in profit is not significant [5][6][7][8]. However, the results of this study are not consistent with the results of research which shows that there is significant difference in the value of ROA between before and after the occurrence of an event (in different periods) [9][10][12].

There is no significant difference between financial performance in terms of NPL values before and after the acquisition. With the occurrence of the takeover of share ownership by bank, it turns out that it has not been able to make a difference to loans categorized as bad, substandard and doubtful and even tends to increase after being acquired. The increasing level of problem loans shows that banks have not been able to make better selections to their customers, so that the expected profit from credit disbursement decreases [5][7][13][14]. However, the results of this study are not consistent with the results of research which show that there are significant differences in the value of NPL between before and after an event (in different periods) [15][16].

There is no significant difference in financial performance in terms of LDR values before and after the acquisition. By looking at the amount of credit granted compared to third party funds, there was a decrease from before the acquisition was made. This means that an increase in the amount of third party funds is not followed by an increase in the amount credit given to the public, this will cause the opportunity for banks to obtain profits from the credit channeled decreased [5][17][18]. However, the results of this study are not consistent with the results of research which shows that there is significant difference in the value of LDR between before and after the occurrence of an event (in different periods) [19][20].

The problem formulation of this research is whether there are differences in the financial performance of banks before and after the Covid-19 pandemic ?. While the purpose of this study is to determine the financial performance of banks before and after the Covid-19 pandemic. Based on empirical evidence and the inconsistency of research results regarding the comparative financial performance of banks before and after the occurrence of an event (in a different period), then a study of " Comparative Analysis of The Biggest Banking Performance In Indonesia ". 


\section{Literature Review}

\subsection{Bank}

Banks are financial institutions whose main activities are collecting funds from the public and channeling these funds back to the community and providing other bank services. Whereas based on the statement of Financial Accounting Standards (PSAK) Number 31, the definition of a Bank is an institution that acts as a financial intermediary between parties who have excess funds and those who need funds, as well as institutions that function to facilitate payment traffic. So it can be concluded that the bank is a financial institution whose main activity is collecting funds from the public in the form of deposits and then channeling funds to the public in the form of credit, and providing other bank services. [21].

\subsection{Financial Performance}

Financial performance is one tool to assess the success of a bank. A banking can be said to be successful if the bank can achieve the objectives of its banking to the maximum, both in the form of profit or market share. In addition, banks can use financial performance for financial planning and forecasting in the future. Financial performance is an analytical technique used to assess banking activities whether the activities carried out have gone well and in accordance with applicable regulations [22]. The measurement of the level of financial performance of banks has the aim to measure and assess the level of effectiveness and efficiency of banks in carrying out operational activities [3].

\subsection{Financial Statements Analysis}

Financial statements are accounting reports that contain information related to transactions that have been carried out. Banks compile financial statements aimed at providing an overview of the banking financial position that serves as a basis for evaluation, planning, and decision making for parties in need, both internal and external [23]. Financial statements have several limitations such as materiality, conservatives, and the special nature of an industry [24]. The analysis of financial statements is a process of processing data on financial statements so that they can be easily understood and understood by readers [2]. The main purpose of the analysis of financial statements is to determine the financial performance of banks in a certain period [3]. Financial statement analysis can be used as a comparison tool between companies engaged in the same industry.

\subsection{Hypothesis Development}

Return on Assets (ROA) is an indicator of a company's profitability. This ratio shows the extent to which an investment can provide a return in accordance with what has been expected where the investment is actually as big as the company's invested assets [3]. A decrease in ROA indicates a decrease in bank profitability. This is due to a decrease in credit extended by banks, so the benefits achieved by banks are also getting lower. This is in line with some research results which shows that there are differences in the value of ROA before and after the Covid-19 pandemic [9][10][11][12][19][20]

$\mathrm{H}_{1}$ : There are differences in the value of ROA before and after the Covid-19 pandemic

The Non Performing Loan Ratio (NPL) is an indicator of credit risk, which shows the ability of bank management to manage loans provided by banks. NPL or non-performing loans is one of the key indicators in assessing bank performance. One of the functions of a 
bank is as an intermediary institution or a liaison between parties who have excess funds and those who need funds. Bank Indonesia (BI) through a Bank Indonesia Regulation (PBI) stipulates that the ratio of problem loans (NPL) is $5 \%$, so the higher this ratio, the worse the quality of bank credit that causes the amount of non-performing loans the greater the possibility of a bank in a condition the problem is greater and allows lower profit achievement [25]. This is in line with some research results which shows that there are differences in the value of NPL before and after the Covid-19 pandemic [15][16].

$\mathrm{H}_{2}$ : There are differences in the value of NPL before and after the Covid-19 pandemic

Rasio Loan to Deposits Ratio (LDR) merupakan rasio yang mengukur kemampuan bank dalam memenuhi kewajiban jangka pendek (likuiditas) dengan membagi total kredit terhadap total Dana Pihak Ketiga (DPK). Likuiditas perlu dikelola dalam rangka memenuhi kebutuhan bank disaat nasabah mengambil dananya dan menyalurkan pinjaman (kredit) kepada debitur. Peningkatan nilai LDR yang terlalu tinggi mengindikasikan perbankan tidak memiliki likuiditas yang cukup memadai untuk menutup kewajibannya terhadap nasabah (DPK). Sebaliknya, semakin rendahnya nilai LDR mengindikasikan perbankan memiliki likuiditas yang cukup memadai namun dengan pendapatan yang lebih rendah, dikarenakan pendapatan sektor perbankan diperoleh melalui penyaluran kredit [3]. This is in line with some research results which shows that there are differences in the value of LDR before and after the Covid19 pandemic [6][14][16][19][20].

$\mathrm{H}_{3}$ : There are differences in the value of LDR before and after the Covid-19 pandemic

\section{Method}

This study uses a comparative quantitative approach that is a study comparing the existence of one or more variables at different samples or times [26] . This study compares the financial performance of banks before and during the Covid-19 pandemic. The population in the study, according to the research title is the largest banking company in Indonesia which is listed on the Indonesia Stock Exchange. The sampling method uses the saturated (census) sampling method. This can be done because the population used is relatively small (less than 30) [26]. Then the sample in this study amounted to 1 bank namely Bank Rakyat Indonesia (Persero) Tbk.

The data in this study are secondary data. This secondary data was obtained from the banking quarterly annual report accessed through the IDX website. Data collection technique used is the documentation technique through the collection of financial statements of Bank Rakyat Indonesia (Persero) Tbk. period 2019-2020. Data obtained by observing, recording and studying descriptions from books, journals, theses, theses, and other literature related to research conducted as well as from the BRI quarterly financial statements for the 2019-2020 period.

The variables used in this study are the variables of banking financial performance as measured by ROA, NPL and LDR. Because this research is a comparison, the data analysis technique used is the Difference Test (Paired Sample T-Test), where the Kolmogrov-Smirnov normality test was previously performed to find out whether the data were normally distributed (parametic) or not (non parametic). In the Kolmogrov-Smirnov normality test the $\alpha$ value used is 5\%, so the result of Sig. $>5 \%$ then the data is normally distributed, but if the Sig value $<5 \%$ then the data is not normally distributed. Through the Paired Sample T-Test with SPSS 20, the results that will appear are the average value of each data, correlation values, and 
hypothesis testing with t-counts on t-tables or through p-values (Sig.). The basis for the decision to accept or reject Ho in this test is as follows.

a. If $\mathrm{t}$ arithmetic $>\mathrm{T}$ table and probability (Asymp.Sig) $<0.05$, then $\mathrm{Ho}$ is rejected and $\mathrm{Ha}$ is accepted

b. If $\mathrm{t}$ arithmetic $<\mathrm{t}$ table and probability (Asymp.Sig) $>0.05$, then Ho is accepted and $\mathrm{Ha}$ is rejected

Paired Sample T-Test test procedure:

1. Determine the hypothesis, namely:

$\mathrm{H} 0: \mu 1=\mu 2$ (the average before and during the Covid-19 pandemic is the same)

$\mathrm{H} 1: \mu 1 \neq \mu 2$ (the average before and during the Covid-19 pandemic is different)

2. Determine a significant level of $5 \%$ or 0.05

3. Determine the testing criteria

a. If $\mathrm{t}$ arithmetic $>\mathrm{T}$ table and probability (Asymp.Sig) $<0.05$, then Ho is rejected and Ha is accepted (there is a significant difference)

b. If $\mathrm{t}$ arithmetic $<\mathrm{t}$ table and probability (Asymp.Sig) $>0.05$, then Ho is accepted and Ha is rejected (no significant difference)

4. Drawing conclusions based on hypothesis testing [27].

\section{Results And Discussion}

\subsection{Research Result}

The results of the three variable normality data test (ROA, NPL, and LDR) at BRI using the Kolmogorov-Smirnov non-parametric statistical test (KS) are explained in the following table:

Table 1. Data Normality Test Results

\begin{tabular}{ccc}
\hline Variable & Sig. Kolmogorov-Smirnov & \multicolumn{1}{c}{ Information } \\
\hline ROA & .171 & Data is normally distributed \\
NPL & .108 & Data is normally distributed \\
LDR & .223 & Data is normally distributed \\
\hline
\end{tabular}

Table 1. illustrates that all variables (ROA, NPL, and LDR) at BRI have a significant value above the sig level. $(\alpha=5 \%)$, so that Ho is accepted which means the data is normally distributed. While different test results ( Paired Sample T-Test ) three variables (ROA, NPL, and LDR) at BRI is described in the following table:

Table 2. Different Test Results ( Paired sample T-Test )

\begin{tabular}{ccc} 
Variable & t count & Sig. \\
\hline ROA & 3.618 & .004 \\
NPL & 2.922 & .127 \\
LDR & 5.132 & .029 \\
\hline \multicolumn{3}{c}{ Source: Data processed, 2020}
\end{tabular}

The different test results in Table 2 . shows that the ROA and LDR variables have Sig. below the level of significance $(\alpha=5 \%)$, Ho is rejected, which means that there are significant 
differences between banking performance before and after the Covid-19 pandemic, which declined after the Covid-19 pandemic. Whereas the NPL variable have a Sig. above the level of significance $(\alpha=5 \%)$, then Ho is accepted, which means that no significant differences between the performance of banks before and after the occurrence of a Covid-19 pandemic.

\subsection{Discussion}

a) Comparison of Return and Asset (ROA) Pre and Post Covid-19 Pandemic

Return on Assets ( ROA ) is an indicator of a company's profitability. This ratio shows the extent to which an investment can provide a return in accordance with what has been expected where the investment is actually as big as the company's invested assets [3]. The analysis shows that the ROA variable at BRI has a significant parameter at the significance level of 5\%. This indicates that there are significant differences between banking performance before and after the Covid-19 pandemic, where the ROA value has decreased after the Covid-19 pandemic.

The results of this study are consistent with some research results which show that there are significant differences in the value of ROA between before and after the occurrence of an event (in different periods) [9][11][12][14][16][18][19][20]. But the results of this study are not consistent with with some research results which show that there is no significant difference in the value of ROA between before and after it occurs an event (in a different period) [5][6][7][8]. The difference in research results occurs because in this study there was a significant decrease in the value of ROA. This is due to a decrease in credit extended by banks, so the benefits achieved by banks are also lower. The decline in credit as a result of the weakening economy after the Covid-19 pandemic. The decrease in ROA ratio illustrates the smaller profit generated by banks. A decrease in ROA indicates a decrease in bank profitability.

b) Comparison of Pre and Post Pandemic Covid-19 Non Performing Loan (NPL) Values

The Non Performing Loan Ratio (NPL) is an indicator of credit risk, which shows the ability of bank management to manage loans provided by banks. NPL or non-performing loans is one of the key indicators in assessing bank performance. One of the functions of a bank is as an intermediary institution or a liaison between parties who have excess funds and those who need funds. Bank Indonesia (BI) through a Bank Indonesia Regulation (PBI) stipulates that the ratio of problem loans (NPL) is $5 \%$, so the higher this ratio, the worse the quality of bank credit that causes the amount of non-performing loans the greater the possibility of a bank in a condition the problem is greater and allows lower profit achievement [25]. The results of the analysis show that the NPL variable at BRI has insignificant parameters at the 5\% significance level. This indicates that there were no significant differences between banking performance before and after the Covid-19 pandemic.

The results of this study are consistent with some research results which indicates that not there are differences significant at a value of NPLs among before and after an event (in a different period) [5][6][7][13][14]. However, the results of this study are not consistent with some research results which show that there are significant differences in the value of NPL between before and after an event (in different periods) [15][16]. Differences occur because the research results in this study there is a decrease in the value of the NPL that is not significant, in other words there is no difference. This indicates that BRI is able to cope with the problem loans 
that occur, so that the bank's condition is getting better. The decline in the value of NPL reflects the achievements of banks in improving the quality of the loan portfolio through the application of the precautionary principle in the loan approval process. In addition, banks are always consistent in applying a disciplined approach, namely " funding before lending" to ensure that bank liquidity is always taken into consideration before making decisions relating to loans.

c) Comparison Value Loan to Deposit Ratio (LDR) Pre and Post-Pandemic Covid-19

Ratios Loan to Deposit Ratio (LDR) is a ratio that measures the ability of banks to meet short-term liabilities (liquidity) by dividing the total loans to total Third Party Fund (DPK). Liquidity needs to be managed in order to meet the needs of banks when customers take funds and distribute loans (credit) to debtors. An increase in the value of LDR that is too high indicates that banks do not have sufficient liquidity to cover their obligations to customers (DPK). Conversely, the lower LDR indicates that banks have sufficient liquidity but with lower income, because the income of the banking sector is obtained through lending [3]. The analysis shows that the LDR variable at BRI has a significant parameter at the significance level of $5 \%$. This indicates that there are significant differences between banking performance before and after the Covid-19 pandemic, where the LDR value has decreased after the Covid-19 pandemic.

The results of this study are consistent with some research results which show that there are significant differences in the LDR between before and after an event (in a different period) [6][14][16][19][20]. However, the results of this study are not consistent with some research results which show that there is no significant difference in value LDR between before and after an event (in different periods) $[5][7][13][17][18]$. The difference in research results occurs because in this study there was a significant decrease in LDR values. This is due to a decrease in the number of loans granted compared to third party funds (DPK) from before the Covid19 pandemic. This indicates that the decline in the amount of credit extended to the public is not followed by a decrease in the amount of third party funds, which will cause a decrease in the bank's opportunity to obtain profits from lending.

\section{Conclusion}

The conclusion of this study is the comparison of financial ratios at BRI in the form of ROA and LDR before and after the Covid-19 pandemic shows that it tends to have significantly different values, while NPL values are not significantly different. In general there are significant differences in the performance of the largest banks in Indonesia before and after the Covid-19 pandemic. There are a number of suggestions that can be given by researchers to BRI and similar subsequent research. The need for increased selection and intensive analysis in lending by banks so as to reduce credit risk and increase income on credit interest. In addition, investment maximization and the use of operational costs are expected to be expected to be efficient, so that banking financial performance will remain optimal without being affected by the occurrence of the Covid-19 pandemic. As for further research, because this research only using BRI during the period 2019-2020 with three variables of the study, expected in ap right to do research on the banking sector as a whole with a longer period spans and using variables for more research, so as to improve the quality of research results. 


\section{References}

[1] D. C. Syafina. (2020, May 10). When corona covid-19 hit the bank sector in various countries [online]. Accessed via https://tirto.id/ketika-corona-covid-19-hasam-sector-bank-diberbagai-negara-eE1H

[2] Munawir. Analysis of financial statements . Yogyakarta: Liberty Yogyakarta. 2012.

[3] I. Fahmi. Analysis of financial statements . Bandung: ALFABETA, cv. 2013.

[4] L. M. Sitanggang. (2020, May 30). Red plate bank performance is still positive until the first quarter of 2020 [online]. Accessed via https://keuangan.kontan.co.id/news/kinerja-bank-pelatmerah-masih-positif-sampai- quarter-i-2020

[5] I. A. Dewi and N. K. Purnawati. Analysis of banking financial performance before and after the acquisition at Bank Sinar Bali. Eud Management E-Journal . Vol. 5 (6). 2504-2531. 2016.

[6] E. Utami. Comparative analysis of financial performance at PT. Bank Pundi Indonesia Tbk. before and after the acquisition. S1 thesis, Indonesian University of Education. 2013.

[7] A. N. Cholifah and Suhadak. Analysis of banking financial performance before and after the establishment of a joint venture (study at PT. Bank Mandiri (Persero) Tbk period 2014 2016). Journal of Business Administration (JAB) . Vol. 42 (1). Pg.115-124. 2017.

[8] A. Salin. Differences in banking financial performance before and after the implementation of good corporate governance (case study at Bank Syariah Mandiri). Journal of Ecomadania . Vol. 1 (2). Page 149-176 . 2018.

[9] M. Ziyad.. Comparative analysis of the financial performance of Bank Muamalat before and after the issuance of the islamic banking profanity fatwa by MUI. Journal of Management and Accounting. Vol. 11 (1). Thing. 46-52.2010.

[10] C. D. Rahmawati and A.B. Sulistiyo. Comparative analysis of financial performance of sharia banking before and after the global economic crisis (case study of Bank Muamalat Indonesia, Bank Syariah Mandiri, Bank Mega Syariah 2006-2010 period). Student Scientific Articles. Jember University Repository. Pages 1-6 . 2015.

[11] A. W. Kurniasari. Comparative analysis of financial performance of sharia banks before and after a spin-off (at the Jabar Banten Syariah Bank). S1 Thesis. Faculty of Islamic Economics and Business. Surakarta State Islamic Institute. 2017.

[12] N. Kresmiati. Comparison of financial performance before and after the 2008 global financial crisis at PT. Bank Syariah Mandiri. S1 Thesis . IAIN Tulungagung. 2017.

[13] R. Lombogia. Comparative analysis of financial performance based on credit risk, market risk, liquidity risk, and liquidity coverage ratio (case study in BUMN go public banks before and after OJK enforcement). EMBA Journal . Vol.3 (3). Pg.798-806. 2015.

[14] A. B. Prima. Analysis of bank financial performance in Indonesia before and after the merger (study on domestic companies merging with foreign ownership). FEB Student Scientific Journal, Universitas Brawijaya . Vol 6 (2). 2018.

[15] Rasim. Financial performance of Indonesian banking before and after the 2008 global crisis (case study at government banks in Indonesia for the period 2003-2013). S1 Thesis . FEB Unila. 2015.

[16] N. K. Widiani et al. Comparative analysis of financial performance of indonesian banking companies before and after the global crisis (study on Indonesian government-owned banking for the period of 2002-2014). Undiksha Journal . Vol. 5 (2). Pages 20-32 . 2016.

[17] Novriza. Comparative analysis of financial performance of government banks and private banks before and after the global crisis. S1 Thesis. Faculty of Economics at the University of Lampung . 2012.

[18] A. D. Kinasih. Analysis of bank financial performance before and after the global crisis (study on national private commercial banks registered on the Indonesia stock exchange for the 2007-2009 period). Thesis . Postgraduate Masters Program in Management UNDIP Semarang. 1-15. 2013.

[19] I. Sisbintari. Comparative analysis of CAR, LDR, ROA and ROE before and after merger at PT. Bank Cimb Niaga Tbk. Profit: Journal of Business Administration . Vol. 6 (2). 163-173. 2012.

[20] S. Alam. Comparison of national banking financial performance before, and after the global financial crisis. Journal of Economic Balance. Vol. 9 (1). 1-10. 2013. 
[21] Kasmir. Analysis of financial statements. Jakarta: Raja Grafindo Persada. 2016.

[22] M. Kusumawati. Comparative analysis of banking financial performance based on the CAMELS and RGEC methods on PT. Bank Mandiri (Persero) Tbk. Journal of Accounting Unesa. Vol 2(2) hal. 1.2012.

[23] C. S. Warren et al. Introduction to Indonesian adaptation accounting (based on the latest PSAK). Edition 25. Jakarta: Salemba Empat. 2014.

[24] Z. Baridwan. Intermediate accounting. Edition 8. Seventh Printing. Yogyakarta : BPFEYOGYAKARTA. 2015.

[25] E. M. Nasser. Comparison of the performance of state banks and private banks with the CAMEL ratio and its effect on stock prices. Media Riset Akuntansi, Auditing dan Informasi. Vol. 3(3). 2013.

[26] Sugiyono. Statistics for research . Bandung: Alfabeta .2014.

[27] M. Kuncoro. Research methods for business and economics . Jakarta: Erlangga. 2010. 